\title{
Factors Influencing Practice of Cashless Purchase During COVID-19 Movement Control Order (MCO) in Malaysian Society
}

Nur Hafizah Yusoff, Muhammad Ridhwan Sarifin, Azlina Zainal Abidin

To Link this Article: http://dx.doi.org/10.6007/IJARBSS/v12-i1/11613

DOI:10.6007/IJARBSS/v12-i1/11613

Received: 09 November 2021, Revised: 11 December 2021, Accepted: 25 December 2021

Published Online: 16 January 2022

In-Text Citation: (Yusoff et al., 2022)

To Cite this Article: Yusoff, N. H., Sarifin, M. R., \& Abidin, A. Z. (2022). Factors Influencing Practice of Cashless Purchase During COVID-19 Movement Control Order (MCO) in Malaysian Society. International Journal of Academic Research in Business and Social Sciences, 12(1), $702-714$.

\section{Copyright: @ 2022 The Author(s)}

Published by Human Resource Management Academic Research Society (www.hrmars.com)

This article is published under the Creative Commons Attribution (CC BY 4.0) license. Anyone may reproduce, distribute, translate and create derivative works of this article (for both commercial and non0-commercial purposes), subject to full attribution to the original publication and authors. The full terms of this license may be seen at: http://creativecommons.org/licences/by/4.0/legalcode

\section{Vol. 12, No. 1, 2022, Pg. $702-714$}

Full Terms \& Conditions of access and use can be found at http://hrmars.com/index.php/pages/detail/publication-ethics 


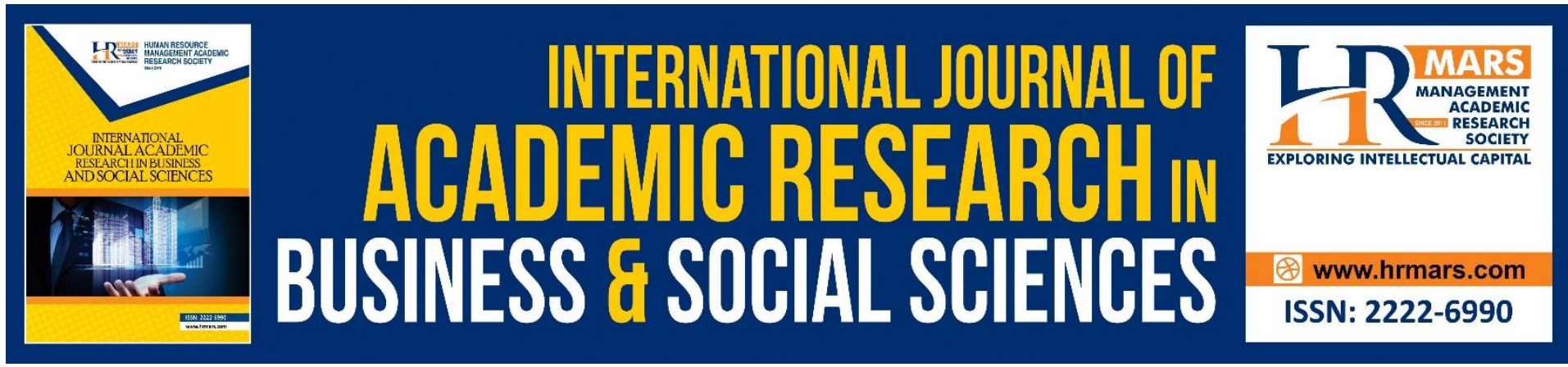

\title{
Factors Influencing Practice of Cashless Purchase During COVID-19 Movement Control Order (MCO) in Malaysian Society
}

\author{
Nur Hafizah Yusoff \\ Anthropology and Sociology, School of Social, Development and Environment (SEEDS), \\ Faculty of Social Sciences and Humanities (FSSK), National University of Malaysia (UKM), \\ Bangi, Malaysia \\ Email Corresponding author: nur_hafizah@ukm.edu.my
}

Muhammad Ridhwan Sarifin

Department of Social and Citizenship Studies (JPKK), Faculty of Human Science (FSK), Sultan Idris Education University (UPSI), Tanjung Malim, Perak, Malaysia

Email: ridhwan.sarifin@fsk.upsi.edu.my

\begin{abstract}
Azlina Zainal Abidin
Anthropology and Sociology, School of Social, Development and Environment (SEEDS), Faculty of Social Sciences and Humanities (FSSK), National University of Malaysia (UKM),

Bangi, Malaysia

Email: p98601@siswa.ukm.edu.my
\end{abstract}

\begin{abstract}
The pandemic of COVID19 required Malaysian government to implement the Movement Restricted Order (MCO) to avoid mass gahthering and maintain the physical distancing. The purpose of this article was to analyse the factors of cashless purchase practice in public society during the period of MCO due to COVID-19 pandemic. In restraining COVID-19 from spreading, the World Health Organization (WHO) has recommended steps such as social distancing. This social distancing indirectly causes increased cashless purchase within the society in Malaysia during the period of MCO. A quantitative approach was used to obtain the data for this research. The questionnaire forms were distributed through google form platform and convenience sampling method was used to obtain the respondents. The research outcome found that there is an increase in cashless purchase practice in public society during MCO. The purchase through cashless practice does not only involve necessities such as food and clothings. Apart from that, the main factor why the society chooses cashless purchase is because it reduces the transmission of COVID-19, to comply with the MCO by the government and because cashless purchase has also become the culture in modern society nowadays. The implication of this cashless purchase is it enhances local economic
\end{abstract}


development and makes room for more job opportunities as runner, deliveryman or personal shopper.

Keywords: Cashless Purchase, E-wallet, Sociology, COVID-19, Movement Restricted Order (MCO)

\section{Introduction}

The spread of Novel Coronavirus (COVID-19) pandemic has been a global issue due to the rise of its cases drastically nearly every day. The World Health Organization (WHO) has reported up to 28th March 2020, this pandemic has sacrificed 23,495 lives and involved 512,701 cases over the world (World Health Organisation, 2020). The daily death statistics involving COVID19 positive across the world has exceeded the total of deaths caused by Severe Acute Respiratory Syndrome (SARS) in 2002-2003 which sacrificed a total of 774 deaths.

Infection related to COVID-19 pandemic is spread through the easiest modes of transmission through contact and droplets from nose or mouth from an infected individual who is positive of COVID-19 when they cough and sneeze. These droplets will cross the surrounding object and surface. Next, other individual is infected with COVID-19 after touching the object or surface, and then touching their own eyes, nose, or mouth. Besides, an individual could be infected with COVID-19 if they stand close to COVID-19 patient who coughs or sneezes or they could get infected from their nose droplets. Therefore, to maintain the distance of more than 1 meter ( 3 feet) from a sick individual should be practiced (Ministry of Health, 2020).

The first wave of COVID-19 pandemic has started in the province of China, Wuhan in last December, 2019. The World Health Organization (WHO) informed that Wuhan is the central location of where COVID-19 started to spread in China. Hence, all layers of society should take precaution to destroy the infection chain by practicing health care as determined like washing hands frequently, using face mask and hand sanitizer, and maintaining social distancing of more than 1 meter from other people to stop the spread of this pandemic. Meanwhile, the World Health Organization (WHO) has also reported that youths are not exempted from being infected of this pandemic.

The World Health Organization (WHO) also declared "emergency" when the new version of coronavirus (COVID-19) which was detected for the first time in Wuhan on $12^{\text {th }}$ December spreaded to other cities and countries in a very short time. As a result of this pandemic transmission, the whole world feels threatened in terms of their health, psychology, and safety aspects in their daily lives. Besides, daily business outside the residence is also affected in regard with work, trade, study, and others must be put into limit and restriction. Malaysia also did not except affected with this pandemic. To control the numbers of infection, Malaysia Government started to implement Movement Control Order (MCO) in March 2020.

\section{Malaysia and Movement Control Order (MCO)}

According to Prime Minister's Office of Malaysia (PMO 2020), Malaysia has taken a smart action in tackling the transmission of this pandemic by implementing Movement Control Order (MCO) under the Prevention and Control of Infectious Diseases Act 1988 and Police Act 1967 which started on $18^{\text {th }}$ March 2020 comprising MCO Phase 1 and extended to now in which it has reached the Recovery Movement Control Order (RMCO) until $31^{\text {st }}$ December 2020. The latest news in Malaysia is mco implemented again and known as MCO 2.0 because of the increasing number of positive cases. MCO 2.0 for most states in Malaysia started from 
13th January until 4th February 2020 with the aim of reducing the number of infections and ensuring adequate health facilities. Movement Control Order comprises total restriction on mass movement or gathering including religious, social and sports activities. Besides, total restriction is also effective on all Malaysian citizens going abroad, travelers from overseas, closure of premises, schools, educational institutions, government, and private premises except for country essential services such as safety, medical, water, electricity, telecommunication, retails, food supply and others (Ridhwan \& Yusoff, 2020). Such drastic action is taken to limit the public movement to restrict the transmission of this pandemic all over the country. During the period of Movement Control Order, the public is ordered to stay home to stop the spread of this pandemic. The slogan Stay at Home is also used to ensure the public will keep staying at home.

Therefore, the routine of necessities purchase practice of Malaysian society has experienced a very drastic change after the government implemented this movement control order (Ridhwan \& Yusoff, 2020). Through the Second and Third Phase of Movement Control Order, it is seen that strict enforcement has been taken to control the movement of society. Hence, in this Second and Third Phase of Movement Control Order, the government only allows a representative or head of family to go out of their residences for purchase of necessities such as food, basic needs, and medicines. Any business involving purchase of necessities is limited to 10 kilometres from their residences respectively starting from $1{ }^{\text {st }} A$ pril to $14^{\text {th }}$ April 2020. As the statistics of COVID-19 decreases, the government becomes more lenient on the movement restriction in which not only the head of family can go out for purchase of necessities. Nevertheless, the public still has doubt in regard with their safety while outside the residences following the virus of COVID-19 that still exists in the community. Other than that, feeling more convenient and safe purchasing online during MCO may lead to more often those activities among public.

This indirectly provides opportunities to many Malaysian citizens to use the alternative of cashless purchase in their daily routine shopping activities and not only because they wanted to comply with COVID-19 Movement Control Order. Therefore, this article focuses on the factors influencing cashless purchase during the period of MCO especially MCO 1-4 in public society in Malaysia.

\section{Literature Review}

As COVID-19 is a new virus, no past research that relates such virus with consumerisme culture has been found. However, the research on cashless society have been studied by a variety of researchers all over the world. Nevertheless, too little research has been done in Malaysian context.

\section{Evolution of Cashless Society}

According to Fabris (2018), cashless society has existed since the period where people use barter system method without real money currency. This statement is supported by Shawal (2016) that barter system is the medium used by past society to obtain items and services by exchanging with other items. Money value at that time is based on trust among society members for exchange of items to obtain items and services. Next, the necessity for money came when the payment and purchase system by the society exists with the use of agreement letter and coins.

Coin currency has started since the $2^{\text {nd }}$ century $B C$ when the Romans introduced denarius coin currency. Meanwhile, in 46 BC, gold denarius coin was falsified in Rome when 
Caesar was the ruler. That was when Roman currency started to comprise gold, silver and bronze denarius coins (Yaacob, 2009). Based on Mohamed Yusof \& Ismail (2011), Ibn Khaldun, the Islamist Sociology Figure, in his famous work of Al-Muqaddimah, argued that gold and silver are among the best currency means to exchange the values for all capitals and also as assets compared to others in which the values keep going up and down. The history also noted that the use of money currency has happened since the era of Prophet Muhammad.

According to Yaacob (2009), paper money was introduced in Song Dynasty, China, in $11^{\text {th }}$ century. The development of money paper started in $7^{\text {th }}$ century, with the production of local money paper. This originated from deposit receipt practice by the traders since Tang Dynasti era (618-907), as the traders and wholesalers wanted to avoid huge amount of copper money in big commercial transaction. Marco Polo, a traveler from Italy introduced paper money to Europe in the $13^{\text {th }}$ century after returning to China. In $19^{\text {th }}$ and $21^{\text {st }}$ century, money evolved in the form of electronic digital parallel with the introduction of digital technology at that time. The first cashless payment was introduced in 1950s and since then, various epayment instruments have been introduced. The payment concept through SMS, debit card, credit card, internet banking and e-wallet are the main results of innovation from past centuries. The cashless society concept relates to bank and bank has enough control over transaction. As a result of this facility, individuals do not have to think about carrying money and only use electronic payment or electronic money (Akinola, 2012).

According to Papadopoulos (2007), technology revolution especially in information and technology field can enhance the development and number of cashless applications. Rapid development of smartphones, 3G / 4G, Wi-Fi, NFC networking and QR code makes information flow faster across the world. This flow of information is not only faster, but easier and much safer, besides being way cheaper. E-transfer infrastructure from day to day becomes more efficient and results in the evolvement from cash to cashless society. Now, money can be transferred through electronic system and can be used by the society all over the world without boundary.

Latest trend shows that cashless concept can be seen based on big amount in financial business performed by the society. However, the real definition of cashless society does not only involve the amount of cashless transaction but regard with the total use of cashless practised by the society (Jain \& Jain, 2017). Thomas (2013) stated that the availability, reasonable product, competitive market and business environment that is dynamic are very crucial factors in determining the success of cashless society concept.

Oman is among the 50 best countries in e-participation of cashless society with the index of 0.7059 and Online Service Index (OSI) of 0.7323 (United Nations, 2014). Oman society uses internet and subscribes mobile phones as much as 159.25 units per 100 people and 50.94 for every 100 people for wireless networking connection. Cole (2012) also stated that $73 \%$ of Americans have accepted the fact that they are moving advanced towards cashless society, away from cash transaction. Many countries like Canada and the United States of America have succeeded in reducing the expense on coin production and currency.

\section{Cashless Buying in Global Context}

Nowadays, cash is replaced digitally where its existence is recorded and converted in the form of electronic digital. The society today makes the cashless practice as a new culture or way of life in daily routine. According to Ali et al. (2019), the development of such cashless payment mechanism is getting more popular and wider in several countries in the year 2010. This is due to the medium of electronic payment such as digital wallet, debit card, digital payment 
system, online banking, smart phone, and digital payment which act as the mediator in business field and banking institution. This digital payment is an indicator that the society today still maintains using cashless transaction in business.

In 2003, ASEAN leaders have drafted the formation of ASEAN Economic Community for the year 2020 aiming to eradicate poverty and socio economic imbalance in ASEAN countries. The community also focuses on the initiative to develop an integrated payment system through cashless medium in Asian region. ASEAN community views cashless practice as a smooth and systematic payment system. Apart from that, it gives benefits to the users and can strengthen ASEAN countries' economy besides widening the scope of access towards financial literacy in digital payment which is also highlighted in ASEAN countries community including Malaysia (ASEAN Secretariat, 2015).

The research conducted by Risbank found that cashless payment habit contributes to $13 \%$ growth in country's economy in Sweden while in Canada, most users have two or more cashless methods like the credit card. Besides, Vietnam announced its initiative to become a country that $90 \%$ practices cashless economy in 2020 . This is following the world trend which is driving towards global cashless society, in line with the trend development of digital economy (Maurya, 2019). Apart from that, the evolution development in financial system and digital technology promotes cashless society today. Technology is one of the elements classified as the factor of social changes. Based on Rohana (2014), social changes happen due to the changes in social institutions of a society which will influence the social system such as values, culture, attitudes and behaviour pattern among society groups. The advancement of technology can change traditional society to a modern society and next towards digital society which connects the world without boundary today in terms of politic, social and economy. Nowadays, internet technology has changed how people deal with payment and money transfer. According to Sahut (2008), the evolution of online mobile payment service has replaced the use of cash money or credit card across the countries. For instance, Paypal in China, a branch of Ebay in 1998, has developed 210 million user base while Alipay had reached 450 million users in 2017. Apart from that, Venmo (USA) and also WeChat Pay (China) which offer e-wallet service using peer-to peer (P2P) payment medium has eased the users to send and receive money from one another digitally. Such a rapid technology is one of the fast social networking integrations to ease payment and attracts 200 million users in three years through We Chat Pay medium and 10 million users through Venmo.

The World Economic Forum Report (2017-2018) stated that technology changes create focus in opportunities and challenges aspects of digital technology that is based on Industrial Revolution 4.0. Besides, items and services offered through cashless purchase receive encouraging feedback from users through social media channels that have rapid technology based on online information, web or data. Such technology advancement is chanelled through smart phones and fast speed internet (World Economic Forum, 2017-2018).

A research in India by Chaudhari (2017) which used test analysis technique ANOVA found that the initiative to create internet facility especially free Wifi zone can increase the use of cashless payment among users. Despite that, such free internet access needs to be monitored by the government to ensure the safety of users in using the free internet channel as a form of assistance in business involving money. Apart from that, all primary banks should have a separate counter or customer service for assistance and guidelines on cashless transaction system to the users. Additional fees for cashless payment shall not incur as a step to encourage towards cashless society. 
Next, cashless use is applied as a culture based on easy and safe factors to the users. Among the benefits are discounts, safety and many reward points after performing payment and purchase. Based on Oneya et al. (2017), electronic payment or cashless system has enhanced life quality by making online payment facility available and business more systematic. This is supported by Cerulus and Contituglia (2018), that digital payment can protect users from being robbed or losing money as a result of carrying cash and wallet frequently. The cashless practice is also said to be successful in reducing the crime rate like bribery.

\section{Experience in cashless buying in Malaysia}

According to Central Bank of Malaysia (2018), sufficient preparation will be made to drive Malaysia towards cashless society as it can generate more efficient economy. Central Bank also explained that cashless buying encourages the shift from financial institution to electronic payment for the sake of saving cost and attaining positive benefits for payment system in this country. In line with that, the government has introduced a digital payment method such as credit card, debit card, e-wallet, internet banking, electronic fund transfer, electronic cash system and online value saving system. Methods that are getting popular in Malaysia are V-cash, Samsung Pay, Ali Pay, Paypal, We Chat Pay and E-Wallet.

After the introduction of cashless transaction system by Malaysian government in 2019, various e-wallet or digital wallet applications have started to develop and accepted by the public. Among the applications that are currently dominating the market are Boost, Touch $\mathrm{n}$ Go, Grab Pay, Fave Pay and Razer Pay. E-Cash Citizen programme was announced by the government during last Budget 2020 presentation. This initiative is an effort to support cashless society in 2020. The use of e-wallet application receives encouraging support by all layers of society in Malaysia (Malaysian Budget Summary Report, 2020).

A research by Nielsen (2016) found that 78\% Malaysian citizens use mobile device to surf social media, and only $34 \%$ use it to purchase items or services. This statistic illustrates the acceptance of cashless purchase platform in Malaysia is still at early phase and low stage. Based on the research, it was also found that $72 \%$ Malaysian citizens do not feel confident about the safety of digital payment platform (Nielsen, 2016). A research by Farhan, Shamsul \& Ahmad (2016) revealed 9 important factors that influence cashless purchase which are safety, product offered, risk, user experience/testimony, main site display, easy and save time, trusted, consumer service and seller's promotion and reputation. The research outome found that $71.3 \%$ respondents think that safety factor is very important in making online purchase.

Based on a research by Treiblmaier et al. (2008), society acceptance regarding cashless payment system is based on the aspects of easy access, quick payment system, safe and trust towards payment system through email verification to the users. The website design and advertisement of reputable companies are believed to become the influencer to the users in making the decision to purchase using online cashless medium. According to Rudresha (2019), the benefits of cashless purchase are it is safer, has more privacy, easy, has discount promotion, easy transaction, and eliminates the need to bring money when shopping. This is proven by their research outcome that most users are more prone to choose debit or credit card as it is the most comfortable payment mode. Users also choose e-wallet as it is safer, easy and gives more privacy to them. The simplicity aspect is the most important factor that influences users towards cashless purchase transaction.

The application of this culture has been practised in items purchase, services, utility bills, fares in public transportation system, flight booking, money remittance and online business. In fact, 
its use has widened especially among millenial generation due to the benefits that it brings particularly in daily spending aspect. Besides, Malaysia is not an exemption in the use of cashless payment by encouraging layers of society especially the youth. The initiative of digitilization cashless literacy needs to be emphasised for youth in both urban and rural areas so that they are not excluded from current technology changes (Malaysian Youth Policy, 2015).

\section{MCO and its Influence towards Cashless Buying}

Since COVID-19 pandemic and MCO precaution measures are still new for world population, therefore not many research are available in the context of cashless transaction during MCO implementation. The latest research was conducted by Karen Webster (2020) through a survey on 2,128 users in the United States of America regarding the purchase attitude during COVID-19 transmission which showed differences compared to daily purchase routine. The reearch outcome found that individuals with annual income of less than 50,000 dollars do not spend much on online shopping due to their capability factor. Apart from that, users in US also plan cashless purchase by using food delivery service and retail purchase during COVID19 as opposed to other seasons previously. Hence, this research and article can contribute towards more research related to consumerism during COVID-19 pandemic by specialising Malaysian society context.

\section{Methodology}

This research used quantitative method as the main method to obtain the research data. The data were obtained through questionnaire survey distribution using google form. This questionnaire form was attached online for a period of three weeks. The questionnaire sets were distributed when Malaysia was in MCO Phase 2. Convenient sampling method was selected to choose the respondents. The respondents were made up of Malaysian society who used cashless platform during MCO because of COVID-19 pandemic. A number of 500 respondents answered the online questionnaires prepared by the researcher. The questionnaire data were analysed using Statistical Package for Social Sciences (SPSS) software. The research outcome was presented in descriptive statistics using frequency, percentage and mean.

\section{Results and Discussion}

\section{Respondents' Sociodemography}

From the total 500 research respondents, $64 \%$ were female respondents and the rest of $36 \%$ were male respondents. In terms of marital status, $53 \%$ respondents are married, and the rest are single. Meanwhile, for occupational status, $88 \%$ respondents are employed in either private or government sectors, or self-employed. The remaining $12 \%$ respondents are fulltime housewives. Almost half of the respondents have an experienced doing an online purchase before the MCO and total of $48 \%$ of respondents never experienced of online purchase and they only get familiar with online purchase during MCO.

\section{Factors of cashless purchase selection during $\mathrm{MCO}$}

There are many factors that influence cashless purchase practice among the respondents during the implementation of MCO by Malaysian government. The factor distribution can be seen in Table 1. 
Table 1: Factors of cashless purchase selection during MCO

\begin{tabular}{|l|c|c|}
\hline Factors & Yes (\%) & No (\%) \\
\hline Precaution steps of COVID-19 Infection & 78.2 & 21.8 \\
\hline Complying with MCO & 76.0 & 24.0 \\
\hline Ease purchase transaction & 74.2 & 25.8 \\
\hline Feeling safe and confident & 70.6 & 29.4 \\
\hline More profitable & 66.3 & 33.7 \\
\hline
\end{tabular}

As stated previously, the research was conducted when MCO was in its second phase. During this second phase of MCO, the leniency was still not given openly to Malaysian citizens to go out to buy necessities, particularly not socialization. Only the head of family can go out for purchased necessities and it shall be within $10 \mathrm{~km}$ radius only. Based on Table 1, 78.2\% respondents revealed their factor of using cashless purchase during MCO was as an effective precaution measure to avoid the transmission of COVID-19 pandemic. WHO also recommends clearly that social distancing is a good method to stop the spread of COVID-19 (Supawittaya et al., 2020). Therefore, cashless purchase is a good choice as there is no direct contact between the seller and buyer (Goel et al., 2019). Such situation can decrease the transmission risk of COVID-19 within the community. These pandemics made people be more precautious about their health. Later, it creates a new norm in term of purchasing among public. They not only made an online purchased but also more convenient to use their digital money either through e-wallet or debit/credit card at the groceries store.

Apart from that, $76.0 \%$ respondents emphasised that they practise cashless purchase to comply with the MCO itself. The government has clearly ordered for this country's citizens to stay home if there is no urgency to go out of their respective residences. If they did not do so, they may be get caught and later will get punishment either money compound or going to jail. Having an MCO, people start to lose the job and some of them got cut the salaries, compound and going to jail is not something that public opt to. Therefore, complying the rule of MCO is the good decision. Hence, most respondents listen to the order and opt for online purchase instead of physical item purchase. The majority of online purchase use cashless payment method (Ramya et al, 2017).

Through cashless transaction, buying becomes easier. The statement is supported by $74.2 \%$ respondents who said cashless purchase makes their business easier. The respondents do not have to go out to buy items, go to the bank or automated teller machine (ATM) to withdraw money to purchase necessities. Besides, now there are many online shopping platforms which indirectly ease cashless purchase in Malaysian society. Moreover, during MCO, more sellers selling necessities like fish and vegetables offer online and cashless purchase. Many groceries store also started to add cashless payment in their store. The respondents also said they feel confident and safe when purchasing with cashless method. $70.6 \%$ respondents agree that cashless purchase especially during MCO increases their confidence and safe feeling when shopping. This safe and confident feeling is supported with no contact when choosing items as everything is done online (Reid, 2020) and do not have to keep money balance from seller. This is because, there is an assumption that paper money is among the means of COVID-19 infection as money always transfers from hand to hand from one individual to another (William, 2020). Hence, it is not surprising that the respondents expressed they feel much confident and safer when performing online purchase and cashless method. However, buyers should take precautions and need to ensure the online platform or sellers do exist. This is 
important to ensure buyers are not easily scammed when payment has been made but the item ordered is not delivered (Mudiana et al., 2018).

66.3\% respondents also stated that cashless purchase is more profitable for them. Respondents mostly buy through online shopping platform such as Lazada and Shopee. Both platforms offer cheaper price and cashback to their customers. Such benefits are not offered when customers buy at physical store. Apart from that, through a variety of e-wallet applications like Boost, QRPay and Touch $n$ Go that offer high reward points and cashback especially when purchasing retail items will bring profit to the users. Users who are used to cashless method will keep using the platform as it makes daily business easier. Meanwhile, for users who have just started using e-wallet, they might feel worried about the safety issue of their personal data. Nevertheless, in Malaysia, Personal Data Protection Act 2010 is an act that protects personal data of this country's citizens againsts irresponsibile parties. Such issue regarding the widened use of cashless purchase practice needs to put into consideration the aspect of user's personal data protection to ensure users will not be the victims of cyber crime later (Ghazali, 2020).

\section{Items purchased with cashless payment}

The items purchased by respondents using cashless payment are good items consisting of necessities or other side items. Table 2 shows the types of items purchased with cashless method by the respondents during MCO.

Table 2: Types of items purchased

\begin{tabular}{|l|c|c|c|}
\hline Types of items & $\begin{array}{c}\text { Percentage } \\
\text { (\%) }\end{array}$ & Mean & Mean Score \\
\hline Retail items (rice, sugar, salt, etc) & 88.2 & 4.07 & High \\
\hline $\begin{array}{l}\text { Wet goods (Fish, chicken, vegetables, } \\
\text { etc) }\end{array}$ & 80.0 & 3.78 & High \\
\hline Readily cooked food & 76.6 & 3.70 & High \\
\hline Electrical \& electronic appliances & 51.3 & 3.16 & Medium \\
\hline Clothings & 50.7 & 3.01 & Medium \\
\hline Beauty products & 42.2 & 2.83 & Medium \\
\hline
\end{tabular}

Table 2 shows the various items purchased with cashless payment during the period of MCO implementation in Malaysia. Retail items recorded the highest mean purchased by respondents which is 4.07. Retail items like rice, sugar, salt, flour and etc are items for daily use. Hence, it is not surprising that it recorded the highest mean. Next, the purchase of these retail items is made through platforms like Lazada, Shopee or using personal shopper or runner services as hired by the respondents. Apart from retail items, wet goods like protein source also recorded a high mean of 3.78. During the implementation of MCO, most households are not able to go out for work. Such situation indirectly witnessed increasing number of people who must stay home following the closure of offices and schools. Shops and food restaurants were also closed resulting in wives and mothers having to increase the capacity of cooking at their residences, respectively. Therefore, wet goods become the item with the second highest mean in the list of purchased items with cashless payment by the respondents during the MCO. 
Next, 76.6\% respondents also stated they purchased readily cooked food with cashless payment during $\mathrm{MCO}$. The increased number of readily cooked food is because they feel bored of their own cooking at home and there are a variety of food available by online sellers (Dang, 2018). If respondents do not use online application such as Grab Food or Food Panda, they still use cahless payment when making purchase using debit or credit card, or e-wallet. The mean value of 3.16 that is moderate was recorded by the purchase of electric or electronic appliances. As the items in this category are not affected in terms of the quantity, therefore respondents do not have to make weekly or monthly purchase. Among the electric and electronic applicances purchased by the respondents during MCO are mobile phone, printer and home internet subscription. Such situation is led by the necessities of working and studying from home during MCO.

The respondents also purchased clothings using cashless payment with the mean of 3.01 recorded for such category. It is because of the MCO and as they are worried of the risk of infection for leaving their residences, which make buying clothes online using cashless purchase is a safer and easier choice for respondents. However, not all respondents like buying clothes without measuring or fitting in first. In fact, there are respondents who are concerned about being deceived in terms of the clothing size and material used. A mean of 2.83 was recorded for purchase of beauty products like facial cleanser, serum, or makeup products. The respondents who made such purchase mostly stated the price offered online is way cheaper than at physical store. Cashless purchase also gives more benefits to them as they could get discount and voucher for next payment and receive cashback.

Prior to MCO, cashless purchase might be unnecessary or unimportant in daily life. However, following the COVID-19 pandemic and precaution measures of MCO being introduced by Malaysian government, it indirectly affects the shopping attitude in this country. Buying online and using cashless payment are considered as one of the new norms (UOW Malaysia KDU, 2020).

\section{Conclusion}

In summary, this research found that MCO has indirectly increased cashless purchase among the society in this country. Although some of the respondents have been done cashless purchase before but during MCO they tend to do more cashless purchase. While others they never have an experienced of cashless purchase before MCO started to make their cashless purchase because to comply the MCO and to keep their life safe from COVID19 infection. Cashless purchase is made either online by online purchasing at website, Facebook, Instagram, or another online platform. Apart from that, cashless purchase also made physically at supermarket, groceries store, restaurants, or coffee shop by using e-wallet or debit/credit card. The compliance with MCO and the concern of getting infected by COVID19 pandemic are found to be the main contributor to why the respondents choose to use cashless purchase. Besides, the implication of this research shows that the society could change according to current necessities. More job opportunities have been created such as personal shopper and runner during MCO when there are many things to buy online. It is also lead to more potential income or part time job can be done by people who are willing to working extra time to make money. There are also various e-wallet applications with each of them offering many facilities and benefits to attract customers to use them. In conclusion, more relevant research could be conducted in the future as e-wallet is still considered as new in Malaysia while its use is increasing these days. Hence, much research from numerous aspects can be studied in the future. 


\section{References}

Akinola, O. S. (2012). Cashless Society, Problems and Prospects, Data Mining Research Potentials. International Journal of Computer Science and Telecommunications, 3(8), 49-55.

Ali, M. F., Harum, M., Abu, N. A., Talib, M. A., \& Al-Mhiqani, M. N. D. (2019). Impact of cashless society on the economic growth in Malaysia. Journal Of Scienc Humanities, 4, 133-142.

ASEAN Secretariat. (2015). ASEAN Economic Community Blueprint 2025. The ASEAN Secretariat Jakarta.

Bank Negara Malaysia. (2018), Mei. Driving Towards Electronic Payments. BNM. March 2018. https://www.bnm.gov.my/.

Cerulus, R., \& Contituglia, R. (2018). Central Bankers Warn of Chaos in a Cashless society. March 2018. https://www.politico.eu/article/centralbankers-fear-cybersecurity-chaosin-a-cashless-society.

Chaudri, T. (2017). The Critical Analysis of Cashless Transaction. International Journal of Commerce And Management Research, 3(3), 92-94.

Cole, M. (2012). Urban Intelligence II-A Cashless Society is Coming Soon. NJ: CUBIC.

Fabris, K. (2018). Cashless Society - The Future of Money or a Utopia?. Journal of Central Banking Theory and Practice, 1, 53-66.

Ghazali, R. (2020). e-wallet - personal data security is top priority. June 2020. https://themalaysianreserve.com/2020/02/03/e-wallet-personal-data-security-is-toppriority/.

Goel, R., Sahai, S., Vinaik, A., \& Garg, V. (2019). Moving From Cash to Cashless Economy: - A Study of Consumer Perception Towards Digital Transactions. International Journal of Recent Technology and Engineering (IJRTE), 8(1), 1220-1226.

Jain, V., \& Jain, P. (1993). Banking Sector In Oman: Strategic Issues, Challenges And Future Scenario. India: College of Banking and Financial Studies.

Kementerian Kesihatan Malaysia. (2020). COVID19. June 2020. http://www.moh.gov.my/.

Arisah, M. F., Badari, Z. S. A., \& Hashim, A., H. (2016). Amalan Pembelian Secara Atas Talian dan Faktor- Faktor Mempengaruhi. Malaysian Journal of Social Sciences and Humanities, 1(3), 111-123.

Maurya, P. (2019). Cashless Economy and Digitalization. Hyedrabad: Himalaya Publishing House.

Yusof, M. F., \& Ismail, M. A. (2011). Money and Economic Growth: Reevaluation of the Role of Money in Imam Al Ghazali's View. Prosiding Perkem VI, Universiti Kebangsaan Malaysia.1; $523-535$.

Mokhsin, M., Aziz, A. A., Zainol, A. S., Humaidi, N., \& Zaini, N. A. A. (2018). Probability Model: Malaysian Consumer Online Shopping Behavior towards Online Shopping Scam. International Journal of Academic Research in Business and Social Sciences, 8(11),15291538.

Nielsen. (2016). Mobile Ecology: Are Malaysian Consumers Ready For The New Frontier Of Mobile Banking \& Payment?. June 2018. https://www.nielsen.com/my/.

Oneya, M., Guvenb, J. V \& Hussain, G. (2017). The Determinants of Electronic Payment Systems Usage From Consumers' Perspective. Journal Of Economic, 30(1), 394-415.

Papadopoulos, G. (2007). Electronic Money and the Possibility of a Cashless Society. Electronic Journal, 1, 22-41.

Ramya, N., Sivasakthi, D., \& Nandhini, M. (2017). Cashless transaction: Modes, advantages and disadvantages. International Journal of Applied Research, 3(1), 122-125. 
Reid, J. (2020). Life after COVID19. July 2020. https://www.dbresearch.com/PROD/RPS_ENPROD/PROD0000000000507960/Konzep t_\%23_18\%3A_Life_after_COVID-19.PDF.

Rudresha, C. E. (2019). Cashless Transaction in India: A Study. International Journal of Scientific Development and Research, 4(2), 116-127.

Sahut, J. M. (2008). The Adoption and Diffusion of Electronic Wallets. Journal of Internet Banking and Commerce, 13(1), 1-10.

Sarifin, M. R., \& Yusoff, N. H. (2020). Reaction of Malaysian citizen towards Movement Control Order (MCO) during the transmission of COVID19 Pandemic. EurAsian Journal of Bioscience, 14(2), 4101-4108.

Shawal, S. A. (2020). Evolusi wang. July 2020 https://www.pressreader.com/malaysia/beritahariamalaysia/20160726/283102773413363.

Supawittaya, P., Yiemphat, P., \& Yasri, P. (2020). Effects of Social Distancing, Self-Quarantine and Self-Isolation during the COVID-19 Pandemic on People's Well-Being, and How to Cope with It. International Journal of Science and Healthcare Research, 5(2),12-20.

Thomas, H. (2013). Measuring Progress Toward a Cashless Society. March 2020. http://www.mastercardadvisors.com/cashlessjourney.

Treiblmaier, H., Pinterits, A., \& Floh, A. (2008). Success Factors Of Internet Payment Systems. International Journal Electronic Business, 6(4), 86-94.

United Nations. (2014). E-Government Survey 2014. June 2020.

http://www.unpan.org/DPADM/EGovernment/UNEGovernmentSurveys/2016U.

UOW Malaysia KDU. 2020, July, 9. Online Shopping Is the 'New Normal' in Malaysia. Uowmkdu. Received from https://www.uowmkdu.edu.my/news/online-shopping-isthe-new-normal-in-malaysia/.

William, C. (2020). Coronavirus could be spread by cash: WHO warns deadly bug can survive on paper money for days - as worldwide cases rise to 106,000 and deaths toll hits 3,600. April 2020. https://www.dailymail.co.uk/news/article-8088067/Coronavirus-spreadcash-warns-WHO.html.

World Economic Forum. (2018). The Global Competitiveness Report 2017-2018. Geneva.

World Health Organisation. (2020). Emergecies disease novel coronavirus 2019. June 2020. https://www.who.int/emergencies/diseases/novel coronavirus-2019.

Yaacob, S. E. (2009). Sejarah dinar emas dan kronologi pertukaran mata wang dunia. Jurnal Al-Tamddun, 4, 107-127.

Yusof, R. (2014) . Asas Sains Sosial Dari Perspektif Sosiologi. Kuala Lumpur: Dewan Bahasa dan Pustaka. 